\title{
ロボットハンドの遠隔把持操作のための 2 指力覚呈示装置の開発
}

\section{Development of two-fingered haptic device for manipulating robot hand}

\author{
○猪飼 丈爾 (神戸大) \\ 小林 太 (神戸大)
}

\author{
福井 航 (神戸大) \\ 小島 史男 (神戸大)
}

\begin{abstract}
George IKAI, Kobe University, 1-1 Rokkodai-cho, Nada-ku, Kobe, Hyogo
Wataru FUKUI, Kobe University, Futoshi KOBAYASHI, Kobe University

Fumio KOJIMA, Kobe University
\end{abstract}

\begin{abstract}
Haptic feedback system is required to provide reaction force resulting in the robot hand to an operator. In this paper, we develop a force feedback device to present reaction force in the operator when the robot hand grasping an object. The force feedback device presents reaction force in distal segment of thumb and middle finger , and basipodite of middle finger. The device is very compact, lightweight and has many force display points by using a Shape Memory Arroy as an actuator.
\end{abstract}

Key Words: Force Feedback, Haptic, Teleoperation, Robot Hand

\section{1 緒言}

マスタースレーブ方式を用いて人の手を模したユニバー サルハンドを遠隔操作し物体把持などの複雑作業を行う 際，カメラ映像などの視覚フィードバックのみで行ってい る. 操作者は物体に触れている感覚がなく作業反力も働か ないため物体を落下させる・把持し損ねるといった問題が ある.これらの器用な動作を実現するためには, 操作者に 触覚・覚情報を伝えることが必要不可欠である. そのた め力覚呈示に関する研究が盛んに行われており，様々な力 覚呈示デバイスが開発されてきた [1][2][3][4].

また, 組み立て動作や開扉動作など, 人は物を操作する ときに手だけでなく腕も協調して動かしており，将来的に ロボットハンドだけでなく加えロボットアームも含めたマ スタースレーブシステムの運用が想定される. ゆえにユニ バーサルハンドの遠隔操作における力覚呈示装置は広い可 動領域を持つ装着型であることが望ましい. また, 把握動 作など指全体を使う動作を行うには基節への力覚呈示が不 可欠である.

本稿では親指の末節および中指の末節と基節への力覚呈 示を可能とするハプティックデバイス ExoPhalanx を開発 し器用な操作を可能とすることを目的とする. タスクの一 例として 2 指による把持操作を挙げ, 開発したハプティッ クデバイスとユニバーサルロボットハンド II[5] を組み合 わせ，遠隔把持操作実験を行うことにより，その性能を確 かめた。

\section{2 仕様}

本節では開発したハプティックデバイスの基本仕様につ いて述べる. ハプティックデバイスはユニバーサルハンド の遠隔操作を想定しているため, 操作者の腕の動きを阻害 しない大きな作業空間や，肩・时・手首の姿勢によらずに
作動することが求められる.これより装着型であることが 望ましい. 装着型である場合, 小型かつ軽量である必要が ある.そこで, 小型化・軽量化のため, 軽量で非常に細い 糸状の形状記憶合金 (Shape-Memory Alloy：SMA) をアク チュエータとして活用する. ハプティックデバイスの機構 および外観を Fig. 1 に示す.

\section{1 力覚呈示装置の機構}

外骨格は中指部, 親指部, 手甲部の 3 つで構成される. 中指部は指の屈伸を阻害しないように更に末節部，中節 部，基節部の 3 つに分かれている. 親指部は末節部と基節 部の 2つで構成される. 手甲部の上に SMA アクチュエー タを $2 つ$ 搭載しており，それぞれ中指基節と親指末節に反 力を生成する.また、中指基節の外骨格の上にも SMA ア クチュエータを搭載している.

\subsection{1 中指の機構}

末節部と基節部に取り付けられた 2 本の力伝達ワイヤは 指の屈伸に合わせて前後する. 末節に取り付けられた DIP ワイヤは基節部上に搭載された DIP アクチュエータ内部 を通っており，DIP アクチュエータが駆動すると DIP ワ イヤを拘束する. 基節部に取り付けられた MP ワイヤは手 甲上に搭載された MP アクチュエータ内部を通っており， MP アクチュエータが駆動すると MP ワイヤを拘束する. MP アクチュエータ下部には末節から伸びる DIP ワイヤが 通っているが，これはガイドの役目を果たしており，MP アクチュエータに拘束されることはない。末節部にはロー ドセルが据え付けられており，操作者が外骨格を押し込む 力を測定する. DIP アクチュエータが駆動し指の動きを拘 束しているとさ, 作用反作用の法則により操作者の押し込 む力が操作者に提示している反力に等しい. 


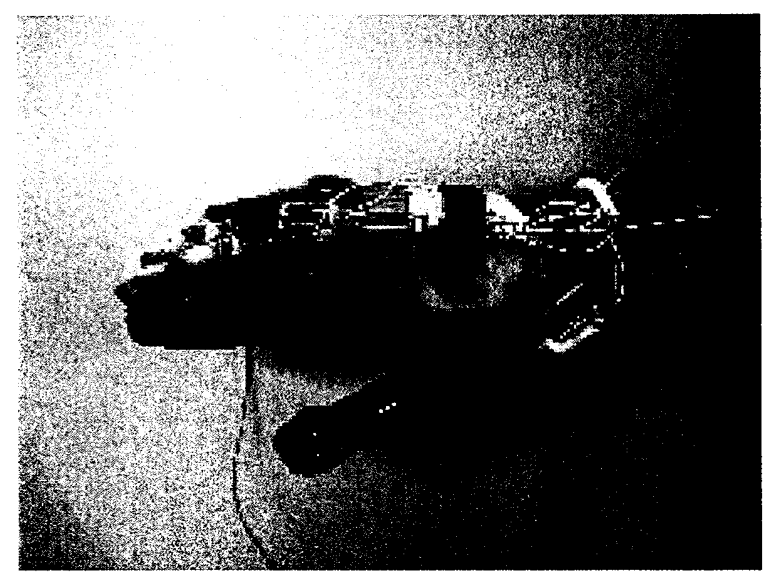

Fig. 1: ExoPhalanx
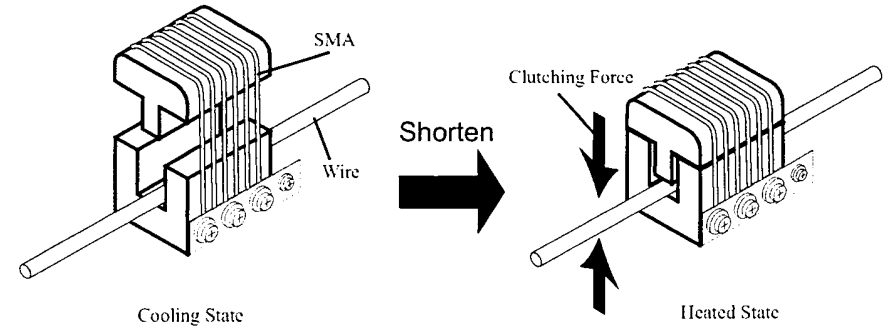

Fig. 2: SMA Actuator

\subsection{2 親指の機構}

末節部に取り付けられた IP ワイヤは基節部のガイドを 通り, 手甲部のIPアクチュエータ内部を通り, IPアクチュ エータが駆動するとIP ワイヤを拘束する. IPアクチュエー タは人の CM 関節の根本上に位置するよう設置している. こうすることで CM 関節の 2 自由度の動きに対応できる. 人の把持動作において物体との接触面は指腹に対して斜め になっていることが多い，そのため，親指末節部の外骨格 は指腹に対して斜めに接触するようになっている.

\section{2 アクチュエータ}

ハプティックデバイスのアクチュエータには小型化・軽 量化のためSMA を使用した. 系状に加工された SMA は, 変態点を超える温度になると長さ方向に収縮する性質を持 つ. 通電によって加熱し収縮させ, この収縮の際に発生す る収縮力をアクチュエータの出力として取り出す. SMAの 伸長は自然冷却によって行う. 本稿では SMA を Fig. 2 の ように配置し，クラッチブレーキとして活用した。 このク ラッチブレーキを用いて, パッシブフォースフィードバッ クを行う。

SMA アクチュエータの制御にはドライバ回路の簡単化 のためパルス幅変調 (PWM) を採用し, 東芝製 ICドライ バ (TA7257P) を用いて実装した. PWMによる制御では Duty 比にクラッチ力が概ね比例することが実験的にわかっ ており，Duty 比を制御することで指の拘束力を制御する ことができる. 本講演では細かな拘束力の制御を行わずに 一定の Duty 比で SMA アクチュエータを駆動する.

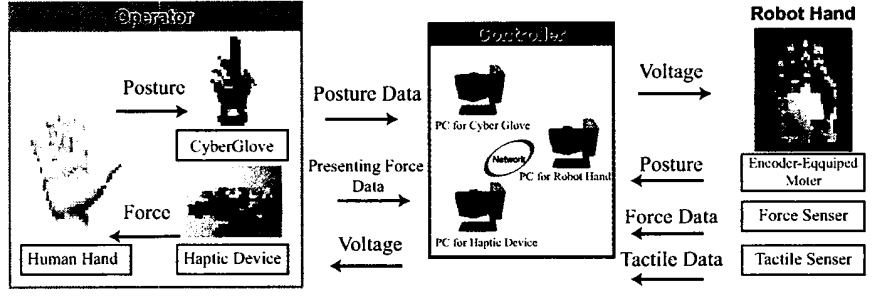

Fig. 3: Haptic System

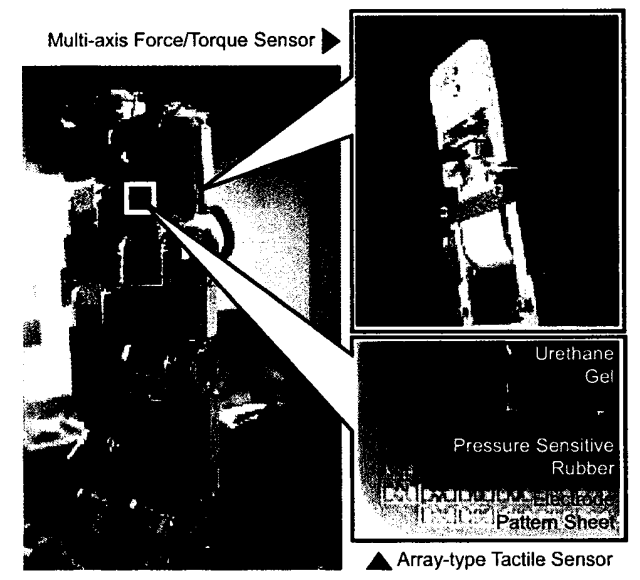

Fig. 4: 6-Axis Force Sensor and Tactile Sensor

\section{3 力覚呈示システム}

ユニバーサルロボットハンドII とハプティックデバイス を組み合わせた力覚呈示システムの構成を Fig. 4 に示す. データグローブを用いて操作者の姿勢情報を取得し, マス タースレーブでユニバーサルロボットハンド II を操作す る. ユニバーサルロボットハンド II の各指指先には 6 軸力 覚センサが内蔵されており, 指腹部には分布型触覚センサ [6] が搭載されている. Fig. ??に 6 軸力覚センサと分布型 触覚センサの外観を示す. 中指基節指腹部の分布型触覚セ ンサは 256 点の計測点を持ち, FPGAを介して通信する. 6 軸力覚センサで検知した垂直抗力が闇值を超えるとハプ ティックデバイスの DIP 関節部の SMA アクチュエータを 駆動させる. 基節指腹部の分布型触覚センサのデータを基 に接触非接触を判断し, 接触しているならばハプティック デバイスの MP 関節部の SMA アクチュエータを駆動さ せる.

\section{4 力覚呈示を備えた遠隔操作実験}

力覚呈示システムを用いて, ユニバーサルロボットハン ド II を遠隔操作しボールを 2 指で把持する実験を行う. 力 覚呈示装置に付けられたロードセルから操作者に提示され る反力を測定し評価する.

\section{1 実験方法}

操作者は CyberGlove と力覚呈示装置を装着している. 操作者はユニバーサルロボットハンド II を遠隔操作し, 手 渡されるボールを親指と中指の 2 指で把持する. 把持する 


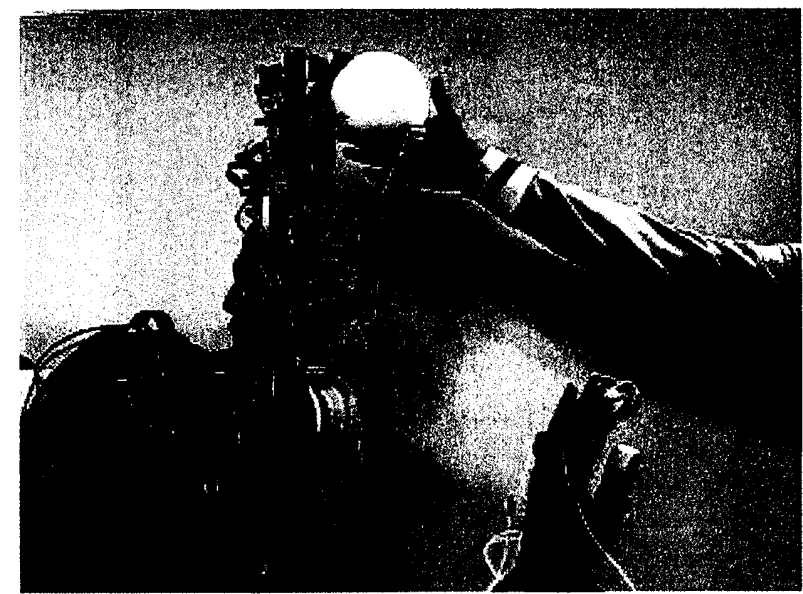

Fig. 5: Experimetal Condition

ボールは発泡スチロール製であり直径は $150[\mathrm{~mm}]$, 人の手 に対するコップや野球ボールと同程度の大きさである，操 作者は以下に従って遠隔操作する。

1. 指の全関節を伸ばした状態で始める.

2. 中指と親指の末節でボールを把持するように指を曲 げる.このとき操作者は反力を感じるまで指を曲げ 続ける.

3. ボールを把持したと判断したら，ボールをはなす.

力覚呈示システムは, マスタースレーブでユニバーサルロ ボットハンド II を制御する。指の 6 軸力覚センサの值 が閾値を超えたら DIP アクチュエータを駆動し DIP 関節 に力覚呈示する. 同様に親指の 6 軸力覚センサの值が䦨值 を超えたら IP アクチュエータを駆動する．実験の様子を Fig. 5 に示す. Fig. 5 は手渡されたボールを把持したとこ ろである. 本実験ではボールを把持する動作を 2 度行った. 1 度目は軽く, 2 度目は強めに把持した。

\section{2 実験結果}

実験結果を Fig. 6, Fig. 7, Fig. 8 に示す. Fig. 6 の (a) はユニバーサルロボットハンド II の中指の 6 軸力覚セン サの值であり，ボールから受けた反力である（b) は外骨 格の中指末節に取り付けられたロードセルセンサの值であ り, 操作者が外骨格を押し込んだ力，すなわち操作者に提 示された提示反力を表している. Fig. 7 はロボットハンド と操作者の中指の DIP 関節角度抢よび MP 関節角度であ る. MP 関節角度は指の屈曲一伸展方向であり，屈曲が正 である. Fig. 8 はロボットハンドと操作者の親指の IP 関 節角度, MP 関節角度および $\mathrm{CM}$ 関節角度である. CM 関 節角度は対立一復帰方向の角度で，対立方向が正である。

(a) および (b) のグラフからボールを把持した際の反力が 操作者に提示されていることがわかる. また Fig. 7, Fig. 8 から反力を十分感じたら屈曲をやめてボールをはなしてい ることがわかる.このとき，(a)では最大 $0.5[\mathrm{~N}]$ 程度の反 力を受けているのに対し，(b) $2.0[\mathrm{~N}]$ 程度まで増幅されて 提示されており両者は一致していない，これは力覚センサ 值が閾值を越えたときにアクチュエータを一定の Duty 比 で駆動しているためであり，入力に比例した出力を行うよ うにアクチュエータを制御していないからである.また,

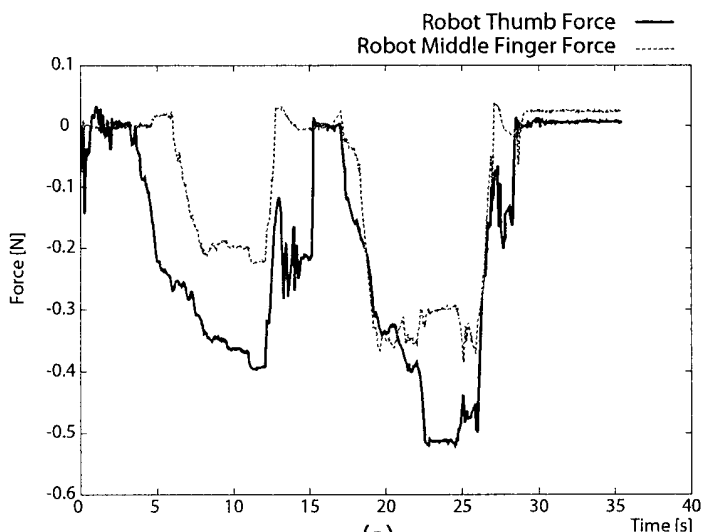

(a)

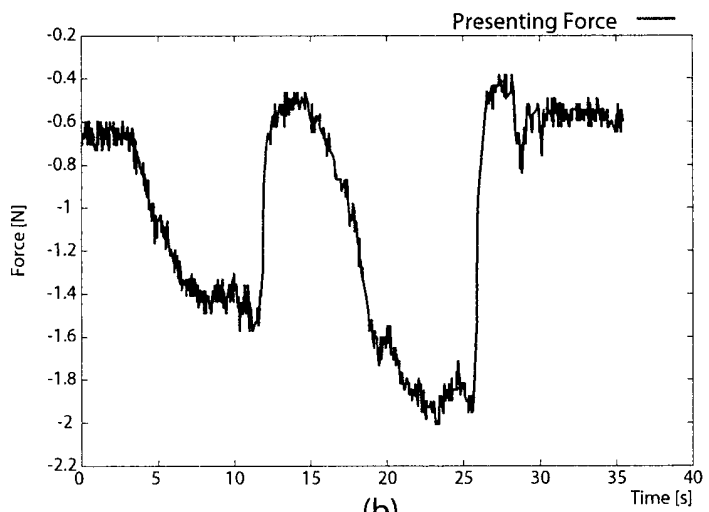

(b)

Fig. 6: (a) Reaction Force applied Robot Middle Finger,(b)Force applied Operator's Middle Finger
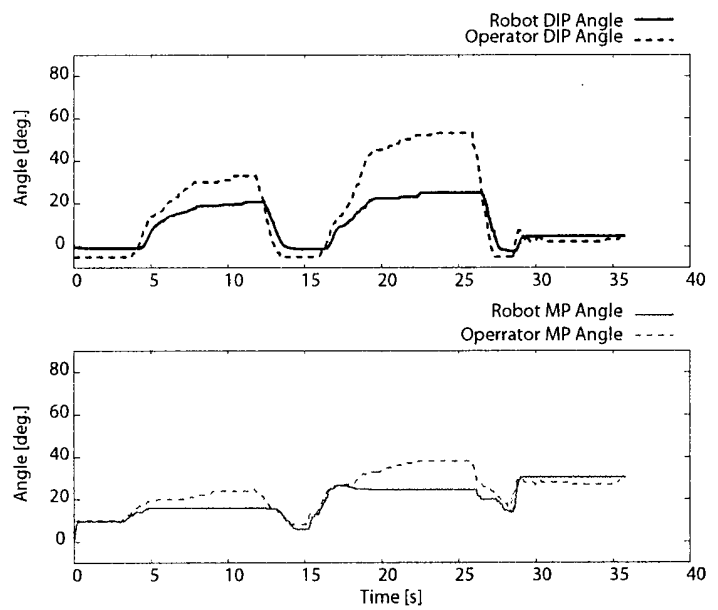

Fig. 7: Angle of Middle Finger RobotHand and Operator 


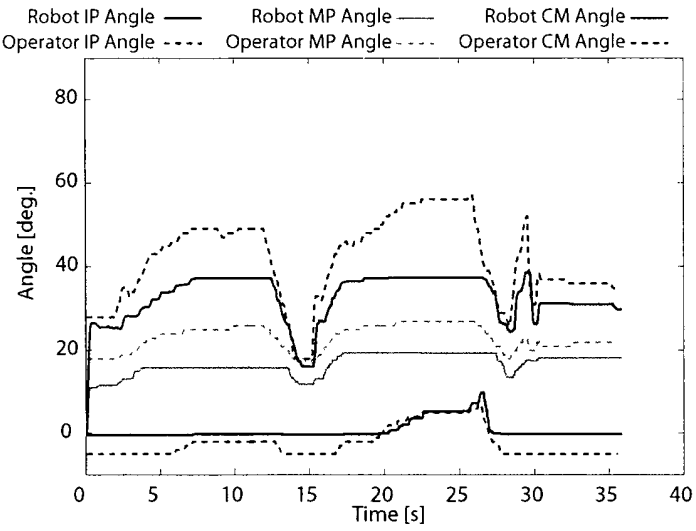

Fig. 8: Angle of Thumb RobotHand and Operator

（b）では初期值が $0.6[\mathrm{~N}]$ ほどあるが，これは外骨格を装着 する際ベルトで締めて固定しているためである.

中指の DIP 関節および親指の $\mathrm{CM}$ 関節について，アク チュエータが駆動した後でも屈曲が進んでいるのは外骨格 の機構的な問題に拠るところが大きい. 手の動きを阻害し ないために，機構に遊びを設けているため力伝達ワイヤを 拘束したとしても若干指を曲げることが可能となっており 機構の改善が必要である.

\section{5 まとめ}

本稿では，指の中指末節，中指基節および親指末節に パッシブフォースフィードバック可能なハプティックデバ イスを開発した. ユニバーサルロボットハンド II を遠隔 操作し, 2 指への力覚提示を可能とする力覚呈示システム を構築した. 2 指での力覚提示を備えた物体把持実験を行 い，ロードセルで提示反力を測定することにより開発した ハプティックデバイスの力覚提示性能を確かめた。

今後はハプティックデバイスの機構の改良とアクチュエー タの改良を行い, 力覚提示性能の向上を図るとともに 5 指 への拡張を行い，5指への力覚呈示を備えた遠隔操作を実 現したい.

\section{参考文献}

[1] Takahiro Endo, Haruhisa Kawasaki, Tetsuya Mouri, Yasutoshi Doi, Tetsunori Yoshida, Yasuhiko Ishigure, Hisayuki Shinomura, Masato Matsumura, Kazumi Koketsu. "Five-Fingered Haptic Interface Robot: HIRO III", Third Joint Eurohaptics Conference and Symposium on Haptic Interfaces for Virtual Environment and Teleoperator Systems Salt Lake City, UT, USA, March 18-20,p458-463, 2009.

[2] Peter Berkelman, Michael Dzadovsky. "Extending the Motion Ranges of Magnetic Levitation for Haptic Interaction", Third Joint Eurohaptics Conference and Symposium on Haptic Interfaces for Virtual Environment and Teleoperator Systems Salt Lake City, UT, USA, March 18-20, 2009.

[3] Mark J. Lelieveld, Takashi Maeno, Tetsuo Tomiyama. "DESIGN AND DEVELOPMENT OF
TWO CONCEPTS FOR A 4 DOF PORTABLE HAPTIC INTERFACE WITH ACTIVE AND PASSIVE MULTI-POINT FORCE FEEDBACK FOR THE INDEX FINGER", IDETC/CIE (2006 ASME International Design Engineering Technical Conferences \& Computers and Information In Engineering Conference), September 2006.

[4] Ken'ichi Koyanagi, Yuki Fujii, Junji Furusho. "Development of VR-STEF system with force display glove system", Proceedings of the 2005 international conference on Augmented tele-existence, Vol. 157, p91-97, 2005.

[5] Wataru Fukui, Futoshi Kobayashi, Fumio Kojima, Hiroyuki Nakamoto, Tadashi Maeda, Nobuaki Imamura, Kazuhiko Sasabe, Hidenori Shirasawa. "Development of Multi-Fingered Universal Robot Hand with Torque Limiter Mechanism", Preprint Proceedings of 35th Annual Conference of the IEEE Industrial Electronics Society, pp2225-2230, 2009

[6] 中本裕之, 小林太, 今村信昭, 白沢秀則, 小島史男. ”工 ニバーサルロボットハンドのための分布型圧力センサ の開発”, 日本機械学会論文集 (C 編), 73 巻, 733 号, pp. 2561-2567, 2007.

[7] 熊沢彰人, 斎藤直樹, 梶川伸哉, 岡野秀晴. ”人間の物 体把持における手の動作に関する実験的考察”，ロボ ティクス・メカトロニクス講演会講演概要集 2003,56 , 1P1-3F-D5, 2003.

[8] 岡田徳次, “指の運動と手作業の分析”, バイオメカ ニズム, no.3, pp. 133-144, 1975 